\title{
Santiago de Chile's morgue: the partial appropriation of the body and the rupturing of funeral rites
}

Jose Manuel Varas Insunza Servicio Médico Legal, Chile

jvaras@sml.gob.cl

\begin{abstract}
This article describes the operational practices of the city morgue in Santiago, Chile and their effects on the family members who come to claim the bodies of their loved ones. It explores the impact of the body's passage through the morgue on the observance of rituals surrounding death and mourning. An underlying conflict can be identified between the state's partial appropriation of and interference with the body and intrinsic needs associated with the performance of funeral rites in accordance with cultural and religious precepts.
\end{abstract}

Key words: morgue, funeral rites, body, anthropology of death

Pain evokes, in some vague way, the presence in every human being of death, of which we are fully conscious, and which reminds us of our finiteness. It is a sign of the contingency of life. To suffer is to be aware of the precariousness of our own condition, in its purest form, against which we have no other defence beyond technology or morality. Nevertheless, although to mankind it may seem to be the strangest, most unfathomable thing, that which besides death seems to him the most intractable is nonetheless the symbol of his humanity. To abolish the capacity for suffering would be to abolish the human condition itself.

(David Le Breton, Anthropology of Pain) [back-translated from the Spanish edition]

This article aims to describe the internal workings of Santiago de Chile's central morgue and to analyse the reactions and emotions that it evokes for those who come here to collect the bodies of their loved ones, brought to this institution for one of a number of possible reasons established by the legal framework of the justice system. ${ }^{1}$ It argues that there is an underlying socio-cultural and human impact created by the state's encroachment on the body in carrying out the forensic autopsy - a procedure, moreover, driven by legal and scientific objectives. This impact can be seen in the interruption to customary funeral rites occasioned by the partial appropriation of the body by the state.

This institution has been connected with death since its origins in 1915, when the Santiago Institute of Forensic Medicine was founded in response to urgent 
public health requirements. Until that point, Chile had no facility where bodies could be managed hygienically, and no trained personnel able to provide professional advice to the law enforcement authorities of the time. ${ }^{2}$ Its name was changed from 'morgue' to Institute of Forensic Medicine out of 'the desire to banish the grim and macabre connotations of death [...] from a place which, for obvious reasons, had a clear link to Santiago's cemeteries [...] being the location where most bodies destined for the common grave were first received' ${ }^{3}$

Today, the Institute, in its advisory role to the courts, produces and submits a range of expert reports based on post-mortem, psychiatric, clinical and laboratory investigations. However, it is its death-related functions that are best known to the public: it is the place where bodies are preserved and forensic autopsies carried out. For more than a century, an integral part of the Institute's work has been concerned with the bodies of the deceased.

A body is taken to the premises of the Forensic Medical Service (SML in Spanish) when legal proceedings are commenced on the order of a judge or public prosecutor. Sometime later, once the forensic examination is complete, family members come to the facility to complete a number of administrative formalities required for the body to be released to them, so that funerary rites can be carried out in accordance with their cultural and religious beliefs.

This study is predominantly based on ethnographic work carried out inside the Institute itself, and on the analysis of data collected through focus groups conducted with bereaved relatives who have passed through it. Through this approach, we are able to construct an account of how family members make sense of this encounter: an experience which is highly charged with values and meanings associated with death, violence and grief, but which is also an expression of an underlying conflict occasioned by the state's proprietary claim over the bodies that arrive here, and which has an influence on the common course of funeral rituals.

\section{A limited state of the art}

Hitherto there has been very little socio-cultural research regarding the internal workings of the morgue in Chile, other than legal or medical studies focusing on professional approaches to mental health, sexology and thanatology, and on the contribution of this work to research and development in the context of the justice system. Among the first authors to approach this topic from a socio-cultural perspective were Varas and Aranguiz, whose 2012 study 'La Representación social (RS) de la ciudadanía respecto al Servicio Médico Legal (la morgue) desde su experiencia y memoria' looked at perceptions of the Forensic Medical Service among the general public in Chile. In the Latin American context, there have been a number of studies relating to the morgue and its material form, as well as artistic and political interventions aimed at highlighting violence, social injustice, repression and drug trafficking in Mexico. ${ }^{4}$ In Colombia, Muñoz's ${ }^{5}$ study entitled 'Surgimiento y desarrollo de los procesos de búsqueda e identificación de personas desaparecidas en Colombia: liminalidad, administración del cuerpo y etnografías del laboratorio y la morgue' presents an ethnographic exploration of the morgue's 
expert services. He argues that scientific investigation is never truly objective, but is mediated by an interplay of social, cultural and religious factors. Salessi ${ }^{6}$ takes a more historical perspective, suggesting that the advent of forensic medicine in Argentina served to 'define and exert control over the spaces in which those who had been arrested and detained were observed, interrogated, and classified, set apart from the bodies of the deceased on which autopsies were conducted. In other words, the bodies of the dead were also subject to observation and interrogation.' The original contribution of this research is not only to look directly at the internal operations of a morgue from a socio-cultural and organisational perspective, but also to demonstrate the impact of this institution's role on the family members who come into contact with it, and on the observance of funeral practices that centre upon the body.

\section{Research objective and methodology}

The research aimed to describe the operations of the city morgue in Santiago de Chile and to construct an account of the reactions and impressions that it evokes for the relatives who come here to claim the bodies of their loved ones, in the context of the observance of funerary rites in accordance with their own cultural traditions.

This study has been based on a qualitative methodology that follows an ethnographic approach. The ethnographic perspective is not only concerned with reporting on the empirical research object itself - for example, a population, culture or society - but also draws on the researcher's own description and interpretation of what he or she saw and heard. Ethnography presents the author's problematised interpretation of some aspect of the 'reality of human action'. ' Data was gathered through participant observation conducted inside the Institute as it carried out its work in relation to the management of bodies. To complement this approach, three group interviews were carried out with bereaved family members who had firsthand experience of this institution. Their accounts enabled me to gain an understanding of the cultural and symbolic aspects of this encounter. Subsequently, thematic analysis was used to categorise the data into dimensions and to identify thematic categories deriving from the collated interviews. This paper presents the main results of the study, focussing on the impressions of the family members who come to the Institute to retrieve the bodies of their loved ones, and the tension that arises between the institution and its users over the possession of the body. This tension is produced by the conflict between the SML's legal and judicial role, on the one hand, and the integrity/rupture of funerary rites, on the other.

\section{The Santiago 'morgue'}

Chile's Forensic Medical Service ${ }^{8}$ is a state institution under the authority of the Ministry of Justice. It is responsible for providing specialist forensic advice to the Courts of Justice and the Office of the Public Prosecutor, through the provision of expert reports on post-mortem, psychiatric, clinical and laboratory investigations. 
However, it is most widely recognised for its role in the management and examination of dead bodies.

To give some idea of the scale of its work, in 2013 there were 99,518 deaths in Chile, of which 37,565 occurred in the capital. Nationally, 11,999 bodies were referred to the autopsy department of the Forensic Medical Services and an examination was ordered in 4,074 cases. In other words, the Santiago city morgue ${ }^{9}$ was required to autopsy 34 per cent of the bodies referred to it on a national level in 2013. ${ }^{10}$

The Institute is situated on the north side of the city of Santiago, next to two cemeteries, a dentistry school, a psychiatric hospital and various other public hospital buildings, creating a pocket of urban space which, intentionally or otherwise, has come to form a single-use enclave where socially sensitive institutions have clustered. In isolation or as a block, these institutions evoke aspects of human experience that are associated with suffering, loss and emotional distress.

Those who come here do so out of necessity, as a result of their connection to matters being investigated by the courts, and this undeniably gives this place a highly charged meaning, associated with aspects of life that we might regard as being 'unpleasant'. The role of this institution, being directly concerned with carrying out autopsies to determine how people died, accounts for the fact that the general public strongly associates it with death: ${ }^{11}$ it is known to everyone in Chile as the city morgue. ${ }^{12}$

\section{Organisational processes inside the morgue: the removal and identification of the body}

The Institute's role in post-mortem investigation begins when an individual dies and the public prosecutor in charge of the case orders the removal of the body. Morgue employees will attend the scene of the death in order to take away the body of the deceased. The removal of bodies takes place all year round, twenty-four hours a day, seven days a week and is carried out by staff working on a shift basis. During daytime hours only the transport van driver attends the scene, whereas at night he or she is accompanied by one of the technicians on duty. At the scene, a form is filled out detailing the name of the deceased (if known), the incident report number, the corresponding public prosecutor's office, the police station of the officer attending the scene and the location of the body. Also recorded are the probable time of death, the place and manner in which the body was discovered, the public prosecutor's order, whether or not any belongings were found on the deceased, the primary cause of death if this can be determined and the name of the police officer completing the form.

When the body arrives on the Institute's premises, all background information is submitted to the administrative office. Once the transport van has arrived, the body is weighed and labelled with a band on the left wrist. Staff make a note of the time of arrival, the name of the driver and the list of belongings found on the body (necklaces, rings, clothing, money etc.), before the body is placed on a metal stretcher trolley and taken to the cold room used for temporary storage and preservation. 
Here, responsibility for the body passes to four young members of staff who work in shifts in the admissions area.

The body is placed on a metal tray inside the interim cold room, which is kept refrigerated to a temperature of between $2^{\circ} \mathrm{C}$ and $3{ }^{\circ} \mathrm{C} .{ }^{13}$ This room, located in the basement of the thanatology building, has an area of about 130 square metres. Mounted on its walls is a rack storage system composed of five rows of modular sections supporting the body trays. The cold room has capacity for approximately thirty bodies, with additional soft-tissue storage. The body will remain here until such time as the relevant forensic examination takes place.

The order in which forensic autopsies are carried out depends on when the bodies arrived at the morgue or were claimed by family members. At the appropriate time the body is taken to the autopsy room on the second floor of the thanatology building. Here, the relevant examination is carried out and samples, fingerprints and photographs are taken. After the autopsy, the body is taken back to the basement level, this time to a second interim cold room identical to the first. It is worth noting that there are other cold rooms which follow a more traditional layout, with bodies stored horizontally in individual compartments. Bodies stored in this way tend to be unclaimed (homeless persons or foreign nationals, for example) and are generally in an advanced state of decay.

The process of identifying the deceased consists primarily of two separate procedures. ${ }^{14}$ First, an attempt is made to identify the body on the basis of fingerprints (which are compared with records held by the Civil Registry and Identification Service). If this is not possible, identification will require the collation of DNA samples; or else visible features, such as scars, tattoos, prostheses, moles and birthmarks or other signs might suggest the identity of the deceased, albeit inconclusively. ${ }^{15}$ Once the autopsy is complete and the body has been identified, it can be released to the family. Bodies that have undergone significant decomposition are much more difficult to identify, calling for the involvement of forensic specialists. In cases where the identity of the body cannot be established with scientific certainty, the Institute will not release it. It will be classified as 'NN' (nomen nescio, or name unknown) until the public prosecutor issues an order for it to be released to the presumed family, passed to an academic institution for scientific purposes or interred in the city's public cemetery.

\section{The handling and examination of the body in the morgue}

The body is removed from the cold room by an autopsy technician using the protocol number (determined by order of arrival) that was previously assigned to it. The technician enters the cold room and proceeds to transfer the body to a stretcher trolley designed for dead bodies. It is then taken to the autopsy room on the second floor. In this room there are nine individual work areas. Here, the specialist in charge of the procedure will be waiting to begin. The body is undressed. First, an external examination is carried out. This involves taking measurements, weighing the body and noting any evidence of rigor mortis or patches of postmortem lividity (discolouration caused by a settling of blood in the lower body). 
The body is checked for any scars, lacerations and/or puncture wounds, amongst other indications. The next stage is the autopsy proper, during which the skull is opened and $\mathrm{Y}$ Y-incision is performed. The organs are removed, weighed on a scale and examined, and various samples are taken. Afterwards, the incisions are closed using hemp sutures. The body is washed and fingerprinted and photographs are taken in accordance with protocol. It is then conveyed to the interim cold room, ready for release.

The SML provides the members of staff who handle the bodies with special clothing, including a Tyvek suit, face mask, overshoes, latex gloves, and goggles, amongst other items. This is a protective measure because dead bodies are often sources of infection and may carry various diseases that can be transmitted through blood or contact with other bodily fluids:

Individuals handling human remains have a small risk through contact with blood and feces (bodies often leak feces after death) from the following: hepatitis B and C; HIV; tuberculosis; diarrheal disease ... Basic hygiene protects workers from exposure to diseases spread by blood and certain body fluids. Workers should use the following precautions: use gloves and boots, if available; wash hands with soap and water after handling bodies and before eating, avoid wiping face or mouth with hands; wash and disinfect all equipment, clothes, and vehicles used for transportation of bodies. ${ }^{16}$

\section{The release and formal recognition of the body}

Bodies are released to the families between the hours of 8.30 a.m. and 6.00 p.m. An average of eighteen bodies are released each day, mostly at weekends. It is not unusual for a crowd made up of members of the public as well as the relatives and friends of the deceased to build up daily around the outside of the building. Many are dressed in black and in tears, waiting to recover the bodies of their loved ones so they can be buried. Even before one enters the building, then, the process of mourning has begun, imposing certain concomitant obligations - refraining from wearing jewellery or bright colours, for example, or from expressing joy. ${ }^{17}$

While the body is in the interim cold room and the autopsy is carried out, immediate relatives can request its release by presenting certain documents required by law. Only two family members (who have been waiting outside the building) are permitted to enter the administrative office. There, once all of the facts of the case have been confirmed, the body has been duly identified and the investigative work has been completed, and on the authorisation of the public prosecutor, the body is officially released. Family members are invited to proceed to the viewing room to carry out the visual recognition of the body. This is done through a glass screen that allows them to see only the deceased's face.

Once this has been done, the body is dressed in the clothing that the relatives have brought with them. Family members do not dress the deceased themselves; this is done by employees of the institution who then, working with the funeral home, place the body in a glass case and perform the final tasks needed to prepare 
it to be seen by mourners. Next, the second and final stage of recognition is carried out, often with the glass case open, during which family members say goodbye to the deceased and place items of religious or symbolic significance with the body: food, money, jewellery, perfume, T-shirts featuring favourite sports clubs, photographs, religious images, rosaries, letters and so on.

When the relatives have said their goodbyes the glass case is sealed and passed into the care of the funeral home, which is responsible for transporting the body to the place where the funeral rites are to be performed. Depending on individual circumstances, the casket may be taken directly to the cemetery, to the family home or to a church for a vigil and subsequent burial ceremony. At this point the other members of the family and community waiting outside the building can begin the process of paying their respects, making their offerings and carrying out the burial ceremony in accordance with local customs and practices.

\section{Death as a traumatic event}

Outside the morgue building, radio journalists and very often TV crews from various networks wait alongside the relatives and friends of the deceased. This means that news reports with some degree of national interest linked to human rights, homicide cases, suicides and traffic accidents are available on a daily basis. In fact, when for some reason the work of the morgue's public employees comes to a halt, this has a negative impact on public perceptions, since the fact that bodies are not being released to families promotes an image of insensitive and inhumane workers, incapable of empathy or of putting themselves in the place of the bereaved.

Those who come to the morgue pay attention to the material, infrastructural and spatial aspects of the building, which is negatively valued due to the uncomfortable conditions in which they are required to wait, outside, to retrieve the bodies of their relatives. This is of no small significance during the winter, when people are often obliged to remain outdoors in cold and wet weather. Family members gather around the entrance to the building, while funeral establishments and food retailers offer their services nearby. The sounds of people weeping and crying out in grief can be heard. Sometimes there is silence. Now and then, employees of various companies and private individuals appear, carrying floral wreaths. It is a long, distressing wait. The absence of a physical space that could provide some degree of comfort while they wait suggests to many a lack of respect for the families.

They expect the building where the bodies of their loved ones are being held to be a dirty, dark and chaotic place, but this isn't the case: the facilities inside the building are clean and hygienic. Although they understand that the body's presence in this institution is required by law and related to scientific work, carried out by professionals in the broader context of the dispensation of justice, it is clear that the experience of the relatives is coloured by death. These are people who are going through a traumatic experience of loss and grief, under circumstances that are psychologically very stressful.

They experience the sensation of being in a situation for which they could never 
be adequately prepared. Invariably, of course, death takes us all by surprise. This uncertainty, this sense of experiencing something traumatic and shocking, manifests itself to some extent in the confusion and disorientation that family members display as they go through the administrative formalities.

\section{The pain of seeing the body}

The intensity of grief will depend on the cause of death, whether it was violent or not, whether it was sudden or expected, and on the age of the deceased. These factors determine how difficult the mourning process will be for the family. Most of the bodies examined by the morgue are referred by the Office of the Public Prosecutor and, as such, belong to the victims of traffic accidents, suicides and homicides: these are shocking and unexpected deaths. Furthermore, the external causes of death often leave the body in a poor condition (broken, disfigured, with visible gunshot wounds etc.), or there may be signs of post-mortem damage (decomposition or bloating), making formal recognition of the deceased a very upsetting moment.

After the recognition the family can move on to the series of administrative steps involved in the funeral process and rites, these being the most direct experiences that bring us into close proximity with death. Due to the circumstances by which the deceased came to be in this institution, the experience tends to be highly traumatic and very painful, and relatives rarely feel welcome.

The first sensation experienced during the ritual process is often a sense of disbelief in what is happening, and of ownership (of wanting to be with the body). Death is an unexpected and shocking event that must be empirically verified by seeing the body and being close to it. Only then is it possible to begin to accept what has happened and the loss that it plainly entails, and to begin the funeral and mourning process. ${ }^{18}$ There is general agreement among the relatives and friends of the deceased that the longer they have to wait for the body, the more painful the experience; and that their only desire in those overwhelming moments is to be able to perform all of the funeral rituals: the last journey, the funeral procession, the burial and the final goodbye.

\section{Belief systems and the necessity of funeral rituals}

The only certain thing in life is death, ${ }^{19}$ and that it comes to us all. In many cultures, death is perceived as a moment of distinctly social significance, in which everyone in the community is a witness and active participant. ${ }^{20}$ While each individual comes to terms with death in his or her own way, we do find certain recurring responses and similarities in different people's perceptions. Death can mean many different things to different people: it can be seen as a biological fact, a rite of passage, something inevitable, a natural event, a punishment, annihilation, the manifestation of God's will, the absurd, separation, reunion, or a just cause for anger, depression, denial, repression, blame, frustration or relief. ${ }^{21}$

During the funeral rites, and particularly when the mourning period begins, the 
bereaved will ask themselves why the person died and left them behind. Depending on their cultural and/or religious beliefs or convictions, death may be seen as a punishment, or else as the manifestation of the will of a divine power. Broadly speaking, the most widespread religious denominations in Chile are Catholicism and Pentecostal Christianity. In this respect:

For Catholics and Pentecostal Christians, the death of the individual signifies the end of physical and corporeal existence on earth and the continuity of the spirit in another place, which is generally referred to as heaven. This belief implies that, in this place, those who have died on earth are reunited with others who have left this world before them, and with their own ancestors. In the Catholic and Pentecostal belief systems, where we go after death will depend on our actions and the kind of lives we have lived in this world, as well as our willingness to repent for those acts that are negatively valued in the normative framework deriving from the moral and ethical teachings of the church itself. ${ }^{22}$

Thus, death may be understood with reference to specific belief systems, all of which share the central idea that there is some form of continued existence after death and that the loved one (or their soul) ${ }^{23}$ will be better off in this place. Every belief system provides its own set of model answers to a wide range of life experiences, including, of course, death. This is why ritual practices are so important; they help to make painful processes more bearable, offering some relief to feelings of abandonment, depression or sadness, amongst others.

Although there are now certain places in which death is perceived in more pragmatic and secular ways, where grief is managed differently and where funeral rituals are perhaps governed by the customs of other times and places, social rites have persisted, and in no community has their significance been lost. As Mircea Eliade observes:

Only the burial ritual is confirmation of death: someone who is not buried according to custom is not dead. Furthermore, nobody's death is validated until the funeral ceremonies have been performed, or until the soul of the deceased has been ritually conveyed to its new dwelling place in the other world, and there admitted to the community of the dead. ${ }^{24}$

\section{Funeral rites, mourning, and liminality}

According to Van Gennep: 'Nothing is so varied, depending on the culture, age, sex and social position of the individual, than funeral rites. ${ }^{25}$ The funeral ceremony is indeed a rite of separation. The concept of liminality has thus been long ago adopted to signify an intermediate phase recognisable as a 'rite of passage': in other words, a ritualised performance established by human societies in order to channel and control the profound changes occurring in the lives of their members, which could pose a threat to their very continuity and reproduction. According first to Van Gennep and later to Turner, rites of passage are composed of three phases: the 
'separation' of the individual or group from the social structure and the prevailing cultural conditions; the 'liminal', threshold or margin phase, when the ritual subject temporarily passes into an ambiguous realm with 'few or none of the attributes of the past or coming state'; and the 'reincorporation' or 'reaggregation' of the subject into the social structure, with all the obligations and rights conferred by his or her new position. The 'liminal' phase in this model is presented as a 'non-state', temporarily independent of and even opposed to established social classifications (neither living nor dead, neither child nor adult). Turner describes the liminal condition as one of being 'neither here nor there', 'betwixt and between the positions assigned and arrayed by law, custom, convention and ceremonial'. ${ }^{26}$ Liminality is a sacred and dangerous state, but rites are imbued with the power to contain and channel it, so as to protect the community's social order. In this respect, those mourning a family member who has died are formed as a ritual community from the very moment the death occurs.

Mourning, ${ }^{27}$ then, as part of this rite of passage, should be understood as a liminal state. Turner ${ }^{28}$ argues that the attributes of liminal personae ('threshold people') are necessarily ambiguous, since this condition and these individuals elude or escape the classification system that normally defines situations and positions in cultural space. Liminal entities are neither in one place nor another; they cannot be situated in any of the positions 'assigned and arrayed by law, custom, convention and ceremonial. As such, their ambiguous and indeterminate attributes are expressed by a rich variety of symbols in the many societies that ritualize social and cultural transitions. Thus, liminality is frequently likened to death'. ${ }^{29}$

Death provokes an emotional, physical and subjective reaction known as grief. However, when somebody dies, a socio-cultural, ritual practice - mourning - also begins. Mourning is an objective state of deprivation, of being dispossessed; it is a complex and variable phenomenon that can be shaped by many different factors. ${ }^{30}$ Thus, the place of the dead body in human society has been encircled by ritual acts carried out in the vicinity of the body, in the form both of funeral rites and, usually, other commemorative rituals that help people to navigate the processes of grief and mourning.

Mourning, therefore, is a state that places the survivors in a marginal position - it is a liminal state, entered through rites of separation, from which they will emerge through rites of reintegration into general society (rites of lifting of mourning). ${ }^{31}$ During the funeral rites the relatives of the deceased form a special society between the world of the living and the world of the dead. They will leave this transitional state sooner or later, depending on the degree of closeness in their relationship to the deceased. ${ }^{32}$

\section{The morgue and the suspension of the rite of passage}

For more modern, urban and secularised societies, death has become an event of interest only to the individual and his or her family, and so this kind of transition rite would appear to have lost its ritual character: the dead are reduced to the information on their death certificates. Nonetheless, Eliade ${ }^{33}$ argues that 
'irreligiousness' is very rarely found in a pure state in social life, even in the most secularised societies. So, even if in the mundane world death, marriage and birth have undergone radical secularisation, it is clear that something has persisted; vague memories of now-defunct religious practices, and a sense of nostalgia, have endured. In this respect, the body, while it remains in the custody of the morgue, is cut off from every sacred and emblematic act of the funeral tradition.

The funerary rites observed in our cities show certain recurring patterns that have not varied over time and which, one way or another, turn us inwards, towards ourselves, the earth, fragility, the unconquerable and many other concepts associated with the idea of fate and the finality of existence. The important thing to understand is that this state institution, in taking custody of the body, places it in a disconnected state, beyond the reach of customary rites. Here, body and soul are suspended in time and space, awaiting the proper socio-cultural response.

Just as Panizo ${ }^{34}$ points out, what we are witnessing here is 'unattended death', where the body's absence disrupts the performance of the collective mechanisms that enable people to cope with the pain of losing a loved one. There is an indeterminate length of time during which the necessary public acknowledgement of death cannot take place, confining the grief, pain and uncertainty to the private sphere. As I have discussed in previous work in the context of the detaineddisappeared, when the bereaved do not have possession or ownership of the body it is placed in a liminal state by force - a state dislocated from the customary rites. This has varying effects on those mourning the deceased.

From the analysis of the data collected, and from the ethnographic observation, two main themes emerge. The first is that the institution exerts proprietary authority over the body (up until the point when the public prosecutor orders its release), while family members, in order to begin saying their final goodbyes, feel an urgent need to carry out the rite of passage or transition; to begin the ceremonial procedures, including formal recognition of the deceased and physical contact with the body. The second is that the bereaved relatives are themselves also in a liminal state, while they wait for the body to be returned to them, to verify its identity and to observe the proper funeral rites in accordance with established social norms. This situation creates a tension between the institution and the relatives of the deceased, who wish to retrieve the body of their loved one.

Applying this analysis to the cultural significance of the funeral rites, from an anthropological perspective all funerary observances are understood as a series of actions directed towards attending to the body: washing it, dressing it and making it ready to be seen, as a way of paying tribute. They also tend to involve the presentation of offerings, in the form of flowers, food or prayers said around the tomb. These actions are all part of a collection of ceremonial practices associated with saying goodbye to the person who has died and ensuring that they do not pass out of memory. The fact that the visual recognition of the body and its return to the family takes place from within this institutional space means, therefore, that the morgue, a secular institution, forestalls the possibility of carrying out the funeral traditions, interfering with the customary unfolding of the rite of passage, of transition, with all its sacred and allegorical qualities. The institution plays a dual role: it 
intervenes in a spatial sense and in appropriating the body, but it also curtails the performance of the funeral rites from the very beginning. Thus, the period that the body spends inside a state institution works against the symbolic effectiveness of the ritual, in the sense that every funeral ceremony must be understood as a rite of passage, meaningful and allegorical, ascribed with a symbolic effectiveness.

The funerary rites, in all their complexity, are truncated; they are suspended in time and space. Furthermore, because every funeral ritual marks a change in both the ontological and the social order, this truncation prevents the deceased person not only from being called to account for the actions that will affect his or her fate in the afterlife, but also from being acknowledged and accepted by the community of the dead.

While the body remains in the morgue, it is not possible to acknowledge and express, through ritual, the social and communal importance of death, which is the purpose of the rite as a societal expression. Turner ${ }^{35}$ suggests that rites exist to mark points of crisis in our lives:

Those in which the ritual subject or subjects move, as Lloyd Warner (1959) has put it, from a 'fixed placental placement within his mother's womb, to his death and ultimate fixed point of his tombstone and final containment in his grave as a dead organism - punctuated by a number of critical moments of transition which all societies ritualise and publicly mark with suitable observances to impress the significance of the individual and the group on living members of the community. ${ }^{36}$

This anomalous situation, the lack of a public ritual, also implies the impossibility of expressing emotion and using rites as a mechanism for reinforcing social bonds. For Paul Irion:

Ritual begins as a spontaneous response to a given situation in order to meet the needs that people cannot express. This is why rituals are so important in crisis situations in which the question of meaning initially stems from emotional more than rational factors ... It is through public ritual that society accepts and pays attention to the grieving process. ${ }^{37}$

It is in the observance of public rituals surrounding death that social ties are strengthened in the hope of shared survival. Through these practices, death is kept at bay by the continuity of the social group: funerals allow people to maintain the impression that death is a culturally controlled and regulated phenomenon ${ }^{38}$ and they help society to address the deaths of their members and to heal the trauma of loss. Rituals also have a more personal, private function for the mourners: they provide an opportunity to express their bereavement within a prescribed framework, and to accept the reality of their loss. For this, they need the body of the deceased to be present.

From this perspective, the waiting relative, whether outside or inside the morgue, is in a suspended state, waiting to take part in a ritual that will reintegrate him or her into society. He or she is also under the influence of extreme emotion. 
Both the mourner and the dead body have been dispossessed. The body, while it is in the custody of the institution, cannot undergo the customary ceremonial rituals. The morgue has appropriated the body; the funeral process is forestalled. It is the state that receives the body and holds the right to perform a forensic autopsy before releasing it to the family. Under normal circumstances these ritual acts are carried out by the family, who see to the arrangement, dressing and washing of the body, all of which are aimed at preparing it for the moment when the community will honour and bid farewell to the person who has died. Only after the body has been released can these rites assume their proper course, with the offerings, wishes for a swift onward journey, the funeral procession, the burial, the final goodbye and the mourning period.

Consequently, we can identify a normative and cultural conflict which has to do with the funeral ritual and the right to possess the body. From the moment when the courts order the body to be removed from the scene of the death, it is the sole preserve of the public prosecutor in charge of the case. Therefore, the body cannot be returned to the family until such time as all investigative procedures ordered by the courts are complete. Thus the body passes into a state of 'partial appropriation', in which the family, amid the natural pain of loss, begins the series of tasks required by law to recover the body. During this interval, which could be a few hours or a few days, mourning rites are suspended in time. Family members gather outside the morgue to await the body's release. The pain and anguish of knowing that the deceased is lying alone in a cold room, and has been operated on, does not help them to bear their loss. The customary rites cannot be performed. The state undresses the body, operates on it and observes it. The ceremonial atmosphere fades and becomes secularised.

\section{Conclusions}

It should be emphasised that there is a certain orthodoxy to institutional procedures, which often involve practices that are alien to people's psycho-social and cultural needs. This (often unnecessary) secularisation tends to be the result of arbitrary policies and procedures that are sometimes obsolete, through which the institution exerts its authority to appropriate the body in violation of socio-cultural bonds and values. ${ }^{39}$

The internal operations of the morgue, like the employees who work in the Thanatology Department's viewing room, play an intrusive role in the ritual process of mourning. It is, of course, highly unlikely that family members and friends would ever be able to participate in the initial stages of the funerary preparations that take place inside the morgue; that is, in the preparation and washing of the body, because the deceased is at that point in the custody of Chile's judicial authorities, as has been the case from the very moment of death. The body cannot be returned to the family until the public prosecutor in charge of the case authorises its release. The bereaved, on arriving at the Institute, want to see, touch and be close to the body; they want to verify its identity and for it to be released as soon as possible. The relative who comes to the morgue has come to 'rescue' the body, to 
recover what has been lost. Widening the scope of the analysis, we see, therefore, that at the centre of this space of interaction is the body of the deceased, mediated by the conflict that arises between the demands of the state's judicial function and the customarily prescribed obligations of the funeral rites. This conflict is itself symptomatic of the tension between modernity and tradition. Here, the façade of the morgue building becomes a physical and symbolic divide between the state and society, the modern and the traditional, the secular and the belief-driven. It is a physical and symbolic threshold, marking and embodying a tension that will be dissipated and returned to its conventional cultural state only once the body has been released and the funeral ceremony has been performed in accordance with cultural and religious precepts.

\section{Notes}

Translated from author's Spanish by Candenza translation

1 In accordance with the current provisions of the Code of Criminal Procedure, the Health Code, and the Civil Code of the Republic of Chile, the bodies of all deceased persons falling into the following categories must be referred to the Forensic Medical Service for autopsy: all deaths occurring under violent circumstances, whether accidental or intentional; all deaths occurring on public roadways or in public places; all deaths where the cause cannot be established and which the examining physician considers to be suspicious; all those who have been admitted as dead on arrival to an accident and emergency department, or who have died after a short stay in hospital and where the cause of death cannot be determined; all hospital patients whose deaths give rise to criminal proceedings, even if the cause of death was a medical condition; all deaths, even if caused by a medical condition, where the identity of the deceased cannot be established from documents or fingerprints; all deaths where the identity of the deceased is unknown.

2 M. Leon, Sepultura sagrada, tumba profana. Los espacios de la muerte en Santiago de Chile, 1883-1932 (Dirección Biblioteca de Archivos y Muesos. LOM Ediciones, Colección Sociedad y Cultura, 1997) p. 257.

3 Leon, Sepultura sagrada, tumba profana, p. 259.

4 Teresa Margolles is a Mexican artist who makes use of photography, installation works, performance art and video to examine physical death from an artistic perspective. For a piece entitled Vaporización, Margolles vaporised water that had been used to wash bodies during autopsy. Her series Autorretratos en la Morgue [Self-Portraits in the Morgue] is a compilation of photographs of unidentified or unclaimed bodies that aims at exploring Mexico's social divisions, while the exhibition Encobijados [Blanketed] displayed the blankets used to wrap up the bodies of the country's execution victims.

5 C. Muñoz, 'Surgimiento y desarrollo de los procesos de búsqueda e identificación de personas desaparecidas en Colombia: liminalidad, administración del cuerpo y etnografías del laboratorio y la morgue.' Paper presented at the 18th National Conference on Legal Medicine and Forensic Sciences of the National Institute of 
Legal Medicine and Forensic Sciences, Santiago de Cali, Colombia, 9-12 August 2016.

6 J. Salessi, Médicos, maleantes y maricas. Higiene, criminología y homosexualidad en la construcción de la nación argentina (Rosario (Argentina), Beatriz Viterbo Editora, 1995) p. 165.

7 D. Jacobson, Reading Ethnography (Buffalo, NY: SUNY Press, 1991) p. 3.

8 The Forensic Medical Service occupies a building designed by the architect Leonello Bottacci, built between 1926 and 1927. The building comprises two storeys, a basement, and a third storey built on the axis of symmetry. It is striking for the continuity of the architectural treatment of its façades, and has housed this institution for nearly a century. Since the turn of the millennium, the Forensic Medical Service has been opening new operational and user support facilities in other locations across the city, due to bureaucratic expansion and the development of new and improved technologies, as well as for various political and administrative reasons. However, this building remains the site of all investigative work and, in particular, it is here that the bodies of the deceased are received.

9 The meaning of the word 'morgue' derives from the French for 'place where bodies are deposited'. It dates from the seventeenth century, when this name was given to the place inside French prisons where the bodies of detainees were kept until they could be identified. Some time later, the term was adopted to refer to the Forensic Medicine Institute in Paris, where unclaimed bodies were displayed.

10 Source: Statistics Department of the Chilean Forensic Medical Service.

11 Newspapers, the television news and other mass media outlets keep a close eye on the building from just outside its grounds, reporting on every murder, suicide, rape or traffic accident that takes place in Santiago. The Institute is also tied up with other events of national importance, for example the vexatious issue of the identification of human remains associated with the human rights abuses committed during the dictatorship, as well as various other highly publicised judicial episodes.

12 Although it is only in the Thanatology Department that autopsies and other operations involving dead bodies are carried out, the public tends to equate the entire Institute with 'the morgue'. This can be established from the results of a qualitative study entitled 'La Representación social (RS) de la ciudadanía respecto al Servicio Médico Legal (la morgue), desde su experiencia y memoria’ published by Aranguiz and Varas in 2012. The authors conclude that, for its users and for the wider population of the city of Santiago, 'the SML is a place where autopsies are conducted, and is therefore the site of scientific and legal work carried out in the context of the dispensation of Justice in Chile ... the SML is a place associated with death, particularly in light of certain national news events'. See Luis Aranguiz and José Varas. 'La Representación social (RS) de la ciudadanía respecto al Servicio Médico Legal (la morgue), desde su experiencia y memoria', Investigación Forense (Instituto Dr Carlos Ybar, Servicio Médico Legal de Chile), 2 (2012): 23-42.

13 'Without cold storage, decomposition advances rapidly. Within 12 to 48 hours in hot climates, decomposition will be too advanced to allow facial recognition. Cold storage slows the rate of decomposition and preserves the body for identification.' 
Cf. Pan American Health Organisation, Management of Dead Bodies after Disasters: A Field Manual for First Responders (Washington, DC: PAHO, 2009), p. 9.

14 Sometimes bodies are also identified from dental records, but at the SML these cases are very much in the minority and most forensic identifications are made through other means.

15 Each body received by the SML is fingerprinted, and so fingerprint records are the most frequently used method of identification and, despite the fact that the prints held on record at the Civil Registry Office are not always of the highest quality, this method remains the most effective. In order to identify a body through facial reconstruction, additional records and background information on the deceased must be obtained. DNA needs to be compared with samples given by the deceased's parents, siblings or children, who in many cases do not come forward or are simply never looked for.

16 Pan American Health Organisation, Management of Dead Bodies after Disasters, p. 6.

17 'Among the earliest symbols produced by man are the three colours [black, white and red] representing products of the human body whose emission, spilling or production is associated with a heightening of emotion.' Thus black is associated with 'excreta or bodily dissolution' and often signifies 'death' or 'darkness'. See V. Turner, The Forest of Symbols: Aspects of Ndembu Ritual (Ithaca, NY: Cornell University Press, 1967). [La Selva de los símbolos, (trans. R. Valdés del Toro and A. Cardín Garay) (Siglo XXI Editores, 1997), p. 98].

18 Still present in Santiago city's collective memory is the 2012 strike, when all activity at the Institute came to a standstill. Unable to claim the bodies of their loved ones, the families stormed the premises, managing to get as far as the cold rooms where the bodies were preserved.

19 For a number of authors who have produced work in the field of the anthropology of death (L-V. Thomas, Antropología de la muerte, (trans. M. Lara) (Mexico City, FCE, 1993) and Philippe Ariès, The Hour of Our Death: The Classic History of Western Attitudes Toward Death over the Last Thousand Years, trans. Helen Weaver (New York, Alfred Knopf, 1975), amongst others) death cannot be reduced to the biological and physical demise of the body, because death is defined through the mediation of certain meanings and symbolisms that vary from culture to culture. Thus death evokes feelings of horror and helplessness in the face of an unstoppable and unknown fate, entirely beyond our control. This explains why we tend to think of death as something remote, which need not trouble our daily lives. In Western society, death is always seen as a process extraneous to the individual; it is an eventuality that one must escape. Similarly, various studies carried out by the Thematic Research Cluster on Death in Chile (part of the Autonomous University Academy of Christian Humanism in Santiago) confirm this understanding: death is seen as a taboo subject, in that it is not regarded as an appropriate topic to discuss openly. We see death as something remote from us: sinister, terrible and immutable.

20 P. Sacramento and J. Bueno, 'Reflexiones acerca del final de la vida. Un estudio 
sobre las representaciones sociales de la muerte en mayores de 65 años', Revista Multidisciplinar de Gerontología, 14:1 (2004), 22-6, https://dialnet.unirioja.es/ servlet/articulo?codigo $=838586$.

21 R. Kalish, La Vejez: perspectivas sobre el desarrollo humano (trans. J. Manuel Cosano) (Madrid, Pirámide, 2004).

$22 \mathrm{~J}$. Varas and C. Sepulveda, Representación social de la Muerte en contextos rituales campesinos: Un estudio de caso en el mundo Campesino de la Zona Central/Costera de Chile (Santiago de Chile: Thematic Research Cluster on Death in Chile at the Autonomous University Academy of Christian Humanism, 2012).

23 In his 1890 book The Golden Bough (a reference to the soul) J. G. Frazer relates the following story: 'Addressing some Australian blacks, a European missionary said, "I am not one, as you think, but two." Upon this they laughed. "You may laugh as much as you like," continued the missionary, "I tell you that I am two in one; this great body that you see is one; within that there is another little one which is not visible. The great body dies, and is buried, but the little body flies away when the great one dies." To this some of the blacks replied, "Yes, yes. We also are two; we also have a little body within the breast." On being asked where the little body went after death, some said it went behind the bush, others said it went into the sea, and some said they did not know.' J. G. Frazer, The Golden Bough (New York: Macmillan and Co., 1890) p. 218.

24 M. Eliade, El Mito del eterno retorno (trans. Ricardo Anaya) (Buenos Aires: Emecé, 2001), p. 100.

25 A. Van Gennep, The Rites of Passage (Abingdon: Routledge, 2004), p. 146.

26 V. Turner, The Ritual Process: Structure and Antistructure (New Brunswick, Aldine, 1969). [El Proceso ritual. Estructura y antiestructura (trans. B. García Ríos) (Taurus, 1988) pp. 95-6].

27 Laura Panizo (see L. Panizo 'Cuerpos desaparecidos. La ubicación ritual de la muerte desatendida'), in C. Hidalgo (ed.), Etnografías de la muerte. Rituales, desapariciones, VIH/SIDA y resignificación de la vida (Buenos Aires, CLACSO Ediciones, 2011, pp. 17-40) builds on the analytical distinction between grief and mourning made by Cordeu, Illia and Montevechio (E. J. Cordeu, E. S. Illia and B. Montevechio, 'El duelo y el luto. Etnología y psicolagía de los idearios de la muerte', RUNA, archivo para las ciencias del hombre 21:1 (1994), pp. 131-55). As a predominantly psychological process, grief is 'the collection of material, mental and symbolic practices that make reference to the one who is no longer alive, and which are above all the responsibility of his or her surviving close family and friends. Mourning, on the other hand, refers to the collective ritual practices that allow the bereaved to be readmitted into the community of the living. Both dimensions (psychological and social) are intimately connected, since the social mechanisms of mourning place great importance on the resolution of the grieving process and vice versa.

28 Turner, The Ritual Process [El Proceso ritual, p. 102].

29 Ibid., p. 95.

30 Van Gennep writes that during mourning social life is suspended for everyone affected, and the length of this period varies according to (a) the strength of the 
natural bond with the deceased (widows/widowers, relatives); and (b) their social position. If the deceased was a chief, this suspension applies to the entire society. See Van Gennep, The Rites of Passage.

31 Ibid., p. 147.

32 'Mourning requirements are based on degrees of kinship and are systematized by each people according to their special way of calculating that kinship (patrilineally, matrilineally, bilaterally, etc.) ... During mourning, social life is suspended by all those affected by it, and the length of the period increases with the closeness of social ties to the deceased (e.g. for widows, relatives) and with a higher social standing of the dead person.' See Turner, The Ritual Process [El Proceso ritual].

33 Eliade, El Mito del eterno retorno, p. 105.

34 Panizo, 'Cuerpos desaparecidos'.

35 Turner, The Ritual Process [El Proceso ritual, p. 168].

36 Ibid., p. 303.

37 P. Irion Manejo de cadáveres en situaciones de desastre (Washington, DC, OPS, 1997), 'Capitulo 4: Aspectos socioculturales', p. 95, http://helid.digicollection.org/ pdf/s8244s/s8244s.pdf.

38 Z. Bauman, Mortality, Immortality and Other Life Strategies (Cambridge, Polity Press, 1992).

39 This is not, however, to deny the necessity of these institutional procedures, or the legal framework governing them; the purpose of this paper is in fact to reflect on the impact of these procedures on the community in terms of the need to incorporate some recognition of socio-cultural needs. 